\title{
EVOLUTION OF FOOD CONSUMPTION PATTERNS AT GLOBAL LEVEL OVER THE LAST FIVE DECADES
}

\author{
Mariana STANCIU1 \\ DOI: $10.35782 / J C P P .2020 .4 .03$
}

\begin{abstract}
The promotion of healthy diets and lifestyles plays an important role in increasing the quality of life, in increasing the life expectancy of the population, in reducing the general morbidity and mortality. The agriculture and food industry sectors have a decisive importance in ensuring the supply of food goods, but equally important are other economic factors that condition the food consumption (population income level, price level, volume and quality of food service supply, habits/opportunities of consumption, preferences and believes, cultural traditions and so on). This article presents some of the main changes registered by the food consumption patterns at global level during the last half of the century. The main chapters of the food consumption patterns considered are the following: the evolution of energetic expression of food consumption, trends in fat consumption, consumption of animal products tendencies, availability and consumption of fish, availability and consumption of fruits and vegetables, the evolution and forecasting of prices. In the concluding chapter is presented also the general expectation regarding food availability and consumption until 2030. The data used here are published by different specialized international institutions like FAO, WHO, WTO or others.
\end{abstract}

Keywords: nutrition, trends, changing, supply, demand

\section{Introduction}

Food is the main source of energy and of nutrition for any living beings and may be usually of animal or plant origin. There are four basic food energy sources: fats, proteins, carbohydrates, and alcohol. Humans are omnivorous beings and consume both plant and animal products.

The food strategies of the states usually aim to ensure food security and safety for social communities, from the perspective of dominant consumption patterns manifest in the social spaces of reference in the respective communities or nations. Within food

\footnotetext{
Senior Researcher, The Research Institute for Quality of Life, Romanian Academy, e-mail:
} mariana3stanciu@gmail.com 
strategies, recommendations have implications in the structure of food chains and can influence population access to basic foods.

The economic development of a country should induce, progressive improving of the food supply including by increasing the quality of the profile services, with consequences in the gradual elimination of deficiencies and deficits of nutritional content of the diets. Thus, the improving of the general nutritional balance of a population might be a goal for a shorter or a longer term because it involves some quantitative but especially qualitative changes in the production, processing, distribution, and marketing of food.

The intensification of urbanization is a factor with major consequences on the dominant food patterns and lifestyles of the peoples. The dynamics of manifesting food consumption decisions as well as some preferences that intervene in the eating behavior of a population, related with specific patterns of employment, or with some models of spending leisure time - can generate some consistent causes of illness for some segments of the population. It is well-known also that accessing either poor or excessive food intakes may generate nutritional disbalances which might mean different nutritional illnesses. Nutrition is a science too expensive to be ignored, if the health of a population is concerned.

FAO publishes annual reports containing food balances and thus provides national food availability data (for almost all goods and for almost all countries).

The food balance sheets provide a complete picture of the supply (production, imports, changes in stocks and exports) and the use of goods (including final demand in the form of food use and non-food industrial use, intermediate demand, such as feed and seed use, and food waste management). From this data, the average supply per inhabitant of macronutrients (energy, proteins, fats) for all foods can be obtained. Although an average supply per inhabitant may be calculated on the basis of national data, the offer refers less to the actual availability of food per inhabitant, as this is also determined by other factors, such as, for example, inequality of access to food of different categories of consumers.

On the other hand, food products available for consumption, for several reasons (for example, the generation of food waste at the household level), cannot be considered equal to food consumption. Therefore, terms such as "food consumption" or "food intake" actually mean "food available for consumption."

Actual food availability may vary by region, socioeconomic level, and season. Some difficulties might be encountered in estimating the changes that occur in the trade, production, and stocks of foods at the level of one year. Therefore, these calculations consider three-year averages to reduce errors.

\section{Energetic expression of food consumption}

In the last half of the century, the world has made significant progress in increasing food availability. Food consumption expressed in kilocalories (kcal) per inhabitant per day is a key variable used to dynamically assess the global and regional food situation. 
Table 1. Global and regional food consumption per inhabitant

(kcal per inhabitant per day)

\begin{tabular}{|l|c|c|c|c|c|c|}
\hline \multicolumn{1}{|c|}{ Region } & $\begin{array}{c}\mathbf{1 9 6 4 -} \\
\mathbf{1 9 6 6}\end{array}$ & $\begin{array}{c}\mathbf{1 9 7 4 -} \\
\mathbf{1 9 7 6}\end{array}$ & $\begin{array}{c}\mathbf{1 9 8 4} \\
\mathbf{1 9 8 6}\end{array}$ & $\begin{array}{c}\mathbf{1 9 9 7 -} \\
\mathbf{1 9 9 9}\end{array}$ & $\mathbf{2 0 1 5}$ & $\mathbf{2 0 3 0}$ \\
\hline Global level & 2358 & 2435 & 2655 & 2803 & 2940 & 3050 \\
\hline Developing countries & 2054 & 2152 & 2450 & 2681 & 2850 & 2980 \\
\hline Near East and North Africa & 2290 & 2591 & 2953 & 3006 & 3090 & 3170 \\
\hline Sub-Saharan Africa* & 2058 & 2079 & 2057 & 2195 & 2360 & 2540 \\
\hline Latin America and the Caribbean & 2393 & 2546 & 2689 & 2824 & 2980 & 3140 \\
\hline East Asia & 1957 & 2105 & 2559 & 2921 & 3060 & 3190 \\
\hline South Asia & 2017 & 1986 & 2205 & 2403 & 2700 & 2900 \\
\hline Industrialized countries & 2947 & 3065 & 3206 & 3380 & 3440 & 3500 \\
\hline Countries in transition & 3222 & 3385 & 3379 & 2906 & 3060 & 3180 \\
\hline
\end{tabular}

* Excludes South Africa

Source: Global and regional food consumption patterns and trends, FAO, 2003

But maybe, a more appropriate term for this variable would be the apparent national average food consumption because the data come from national food balance sheets, rather than from food consumption surveys.

FAOSTAT data attests that, globally, between 1964-2015, food intake in caloric expression, has increased steadily; the availability of calories per capita from the mid-1960s to the end of the 1990 s increased globally by approximately $450 \mathrm{kcal}$ per capita per day and by over $600 \mathrm{kcal}$ per capita per day in developing countries (Table 1).

But this dynamic has been clearly differentiated between regions. Caloric intake per inhabitant was almost stagnant in sub-Saharan Africa and, during the 1990s, declined in countries in economic transition. In contrast, the caloric intake per inhabitant increased massively in East Asia (with almost $1000 \mathrm{kcal}$ per inhabitant per day, mainly in China) and in the Near East / North Africa (over 700 kcal per inhabitant per day).

The increase in food consumption globally was accompanied by significant structural changes and a change in diets in relation to some products, such as roots or tubers, in order to increase the consumption of products of animal origin and vegetable oils (Tables 3 and 4). Table 1 shows that the energy supply varied, in 2015 from $2850 \mathrm{kcal}$ per inhabitant in developing countries, to $3060 \mathrm{kcal}$ per capita per day in transition countries and $3440 \mathrm{kcal}$ per inhabitant in industrialized countries.

Table 2. Plant or animal energy sources in the diet (kcal per capita per day)

\begin{tabular}{|c|c|c|c|c|c|c|c|c|c|c|c|c|}
\hline \multirow{2}{*}{ Region } & \multicolumn{3}{|c|}{1967 - 1969} & \multicolumn{3}{|c|}{1977 - 1979} & \multicolumn{3}{|c|}{1987 - 1989} & \multicolumn{3}{|c|}{1997 - 1999} \\
\hline & $T$ & $\mathbf{V}$ & $\overline{\mathbf{A}}$ & $\mathbf{T}$ & $\mathrm{V}$ & $\overline{\mathbf{A}}$ & $\mathbf{T}$ & $\mathrm{V}$ & $\mathbf{A}$ & $\mathbf{T}$ & $\mathbf{V}$ & $\overline{\mathbf{A}}$ \\
\hline $\begin{array}{c}\text { Developing } \\
\text { countries }\end{array}$ & 2059 & 1898 & 161 & 2254 & 2070 & 184 & 2490 & 2248 & 242 & 2681 & 2344 & 337 \\
\hline $\begin{array}{c}\text { Countries in } \\
\text { transition }\end{array}$ & 3287 & 2507 & 780 & 3400 & 2507 & 893 & 3396 & 2455 & 941 & 2906 & 2235 & 671 \\
\hline $\begin{array}{c}\text { Industrialized } \\
\text { countries }\end{array}$ & 3003 & 2132 & 871 & 3112 & 2206 & 906 & 3283 & 2333 & 950 & 3380 & 2437 & 943 \\
\hline
\end{tabular}

Note: T- total kcal; V- kcal of vegetable origin; A - kcal of animal origin (including fish)

Source: ***Global and regional food consumption patterns and trends, FAOSTAT, 2003 
Between 1967-1999, the caloric intake per inhabitant / day from animal and / or vegetable sources, in transition countries decreased, while in developing countries, but especially in industrialized countries, it increased (table 2). The caloric availability of animal type has become somewhat more balanced in developing and industrialized countries, meaning that the ratio of $\mathrm{kcal} /$ capita / day in industrialized countries / developing countries decreased from 5.4 in 1967- 69 to 2.8 in 1997-99.

Similar trends were observed regarding protein availability; it has grown in both developing and industrialized countries but has decreased in transition countries. Although the global supply of protein has increased, the distribution of increased protein intake has been uneven. The supply per inhabitant with vegetable protein was slightly higher in developing countries, while the supply of animal protein was three times higher in industrialized countries.

The main types of cereals consumed in the dominant pattern of consumption al global level are rice and wheat, whose added consumed quantities has grown from 800 to over $1,000 \mathrm{kcal}$ per capita, after the year 1980, on the background of the demographic increase (since the early 1960 world `s population has doubled until 2020, at 7.8 billion (Hannah Ritchie and Max Roser, 2020).

Graph 1. The weight of the energy diet derived from cereals

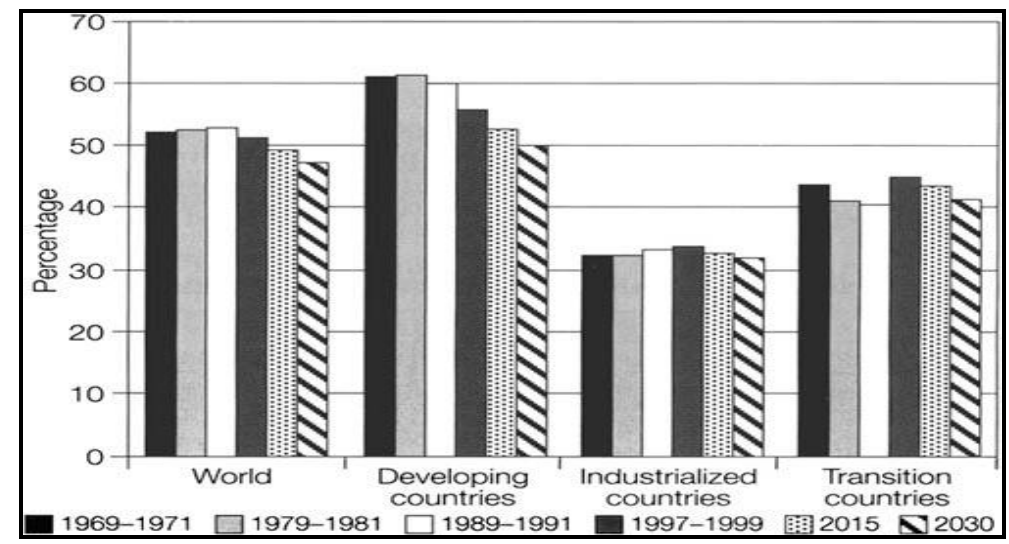

Source: *** World agriculture: towards 2015/2030. Summary report. Rome, Food and Agriculture Organization of the United Nations, 2002

Globally, the share of caloric intake of cereals seems to have remained relatively stable over time, accounting for about $50 \%$ of total caloric intake (Graph 1).

However, some subtle changes have taken place. An analysis of food energy intake shows its decrease in developing countries, where the share of energy derived from cereals has decreased from $60 \%$ to $54 \%$ over a period of only 10 years. Much of this downward trend is attributed to cereals, especially wheat and rice, which are becoming 
less preferred foods in middle-income countries, such as Brazil and China, and this pattern is likely to continue to be structured until 2030 .

\section{Trends in fat consumption}

Fat is a generic term for a class of lipids, that are produced by organic processes both in animals and plants. Saturated fats include animal fats (e.g. milk fat, lard, tallow), and palm oil, coconut oil, cocoa fat, and hydrogenated vegetable oil. Vegetable fats, coming from olive, peanut, maize (corn oil), cottonseed, sunflower, safflower, and soybean, are predominantly unsaturated. Both vegetable and animal fats contain saturated and unsaturated fats. Some oils (such as olive oil) contain in majority monounsaturated fats, while others present quite a high percentage of polyunsaturated fats (sunflower, rape ${ }^{1}$

Increasing the quantity and quality of fat consumption is an important feature of the nutritional transition reflected in the national diets. There are large differences between the regions of the world in terms of the total amount of fats (fats in food plus added fats and oils) available for human consumption. The smallest quantities consumed are registered in Africa, and the largest consumption occurs in parts of North America and Europe. There has been a remarkable increase in fat consumption during 1967-1999 (Table 3), practically everywhere excepting Africa, where consumption levels have stagnated. The fat intake per inhabitant of animal feed increased by $14 \mathrm{~g}$ per inhabitant in developing countries and by $4 \mathrm{~g}$ per inhabitant in industrialized countries, while in the transition countries this type of consumption decreased $9 \mathrm{~g}$ per inhabitant.

Regarding human nutritional needs, proteins come in two forms: complete proteins which contain eight amino acids that humans cannot produce themselves, and incomplete proteins which contain only a small proportion of one or more amino acids. Humans' bodies can use all the amino acids they extract from food for synthesizing new proteins, but some of the inessential ones need not be supplied by the diet, because our cells can make them ourselves. Animal-derived foods contain all those amino acids, while plants are typically stronger in some acids than others. Complete proteins can be made in an all vegan diet by eating a sufficient variety of foods and by getting enough calories. Protein deficiency can lead to different symptoms such as fatigue, hormonal irregularities, insulin resistance, loss of muscle mass, low body temperature and others. Severe protein deficiency may be fatal ${ }^{2}$

The increase in fat intake worldwide has exceeded the increase in protein intake. The global average fat intake increased by $20 \mathrm{~g}$ per capita per day, from 1967 to 1999. This increase in fat availability was more pronounced in America, East Asia, and the European Community. The proportion of energy with which food fats contributed has exceeded 30\% in industrialized regions, and in almost all other regions this weight has increased (fat-energy ratio (FER) is defined as the percentage of energy derived from fats in the total energy supply (The analysis of FAO data for each country between 1988 and 1990 revealed a range for FER of 7-46\%. A number of 19 countries

${ }^{1}$ Food Molecules (2020), available at https://www.worldofmolecules.com/foods/

${ }^{2}$ Food Molecules (2020), available at https://www.worldofmolecules.com/foods/ 
fell below the minimum recommendation of $15 \%$ of the food energy from fats, most of them being countries. from Sub-Saharan Africa, and the rest from South Asia (FAOSTAT, 2003). Instead, 24 countries exceeded the maximum recommendation of $35 \%$, most of them from North America and Western Europe. The data limits in the food balances have skewed. probably some variations of FER from different countries. For example, for Malaysia, which has an abundance of low-priced vegetable oils, the data $\mathrm{b}$ food balance may not reflect actual consumption at the individual household level. Increased incomes in the developing world have led to increased fat availability and consumption.

Food balance data can be used to examine the change in the proportion of fat intake over time and its relationship with income growth (Guo X et al., 2000).

Table 3. Trends in dietary fat intake

\begin{tabular}{|l|c|c|c|c|c|}
\hline \multirow{2}{*}{ Region } & \multicolumn{5}{c|}{ Fat intake (g per capita per day) } \\
\cline { 2 - 6 } & $\begin{array}{c}\mathbf{1 9 6 7 -} \\
\mathbf{1 9 6 9}\end{array}$ & $\begin{array}{c}\mathbf{1 9 7 7 -} \\
\mathbf{1 9 7 9}\end{array}$ & $\begin{array}{c}\mathbf{1 9 8 7 -} \\
\mathbf{1 9 8 9}\end{array}$ & $\begin{array}{c}\mathbf{1 9 9 7 -} \\
\mathbf{1 9 9 9}\end{array}$ & $\begin{array}{c}\text { Growth between } \\
\mathbf{1 9 6 7} \text { and } \mathbf{1 9 9 9}\end{array}$ \\
\hline Global level & 53 & 57 & 67 & 73 & 20 \\
\hline North Africa & 44 & 58 & 65 & 64 & 20 \\
\hline Sub-Saharan Africa* & 41 & 43 & 41 & 45 & 4 \\
\hline North America & 117 & 125 & 138 & 143 & 26 \\
\hline Latin America and the Caribbean & 54 & 65 & 73 & 79 & 25 \\
\hline China & 24 & 27 & 48 & 79 & 55 \\
\hline East and Southeast Asia & 28 & 32 & 44 & 52 & 24 \\
\hline South Asia & 29 & 32 & 39 & 45 & 16 \\
\hline The European Community & 117 & 128 & 143 & 148 & 31 \\
\hline Eastern Europe & 90 & 111 & 116 & 104 & 14 \\
\hline Near East & 51 & 62 & 73 & 70 & 19 \\
\hline Oceania & 102 & 102 & 113 & 113 & 11 \\
\hline
\end{tabular}

Note: ${ }^{*}$ Excludes South Africa

Source: FAOSTAT, 2003.

Between 1961-1963, a diet that provided $20 \%$ of energy from fats was associated only with countries that had at least a GNP per capita of \$1475. Until 1990, however, even the poor countries that had a GNP in place. only US $\$ 750$ had access to a similar diet comprising $20 \%$ of energy from fats (both GNP values are expressed in USD \$ 1993.) This change was mainly the result of increased vegetable fat consumption in poor countries, and of smaller increases in middle- and high-income countries. Until 1990, vegetable fats had a higher caloric intake than animal fats for the countries with the lowest incomes per inhabitant. Changes in the supply of edible vegetable oils, changes in prices and consumption affected both rich and poor countries, but the net impact was higher in low-income countries (Drewnowski A, Popkin BM., 1997).

In 2010, mean global saturated fat intake in adults was $9.4 \%$ of energy intake, with marked variation across regions and countries. Highest intakes were identified in Samoa and similar palm oil producing island nations, as well as Sri Lanka, Romania, and Malaysia. Lowest intakes were in Bangladesh. In 75 of 187 countries, representing 
2.73 billion adults and $61.8 \%$ of the global adult population, mean consumption was $<10 \%$ of energy intake ${ }^{1}$

Worldwide 2010, omega 6 polyunsaturated fat mean intake was $5.9 \%$ of energy intake with approximately 3 -fold variation between highest (8.5\% of energy intake) and lowest (2.5\% of energy intake) regions. Country-specific intake ranged from $1.2 \%$ of energy intake to $12.5 \%$ of energy intake. Highest intake was in Bulgaria. The lowest intakes were in Kiribati, Samoa, and Vanuatu. Only one of 187 countries (Bulgaria) had intakes at or above the optimal level of $12 \%$ of energy intake. Only 94 of 187 countries had intakes at or above $5 \%$ of energy intake, representing 2.3 billion adult people and $52.4 \%$ of the world adult population ${ }^{2}$

Globally 2010, mean dietary cholesterol intake was $228 \mathrm{mg} /$ day. Across the Global Burden of Diseases Study regions, roughly 2.4-fold differences were identified, and across countries 4.5-fold differences (from 97 to $440 \mathrm{mg} /$ day). Romania, and other Eastern European nations, such as Latvia and Belarus, as well as Algeria, Paraguay, Japan, and Hungary had highest consumption. Lowest intakes were in Bangladesh, Nepal, other South Asian nations, and East Sub-Saharan African nations such as Rwanda and Burundi. Overall, 155 of 187 countries had mean cholesterol consumption $<300$ $\mathrm{mg} / \mathrm{day}$, in line with current recommendations, representing 3.9 billion adults and 87.6 $\%$ of the world adult population. Both regionally and nationally, dietary cholesterol did not strongly correlate with saturated fat consumption ${ }^{3}$

Globally 2010, mean intake of seafood omega 3 fats was $163 \mathrm{mg} /$ day, with tremendous regional variation (from $<50$ to $>700 \mathrm{mg} /$ day) and national variation (from 5 to 3886 $\mathrm{mg} /$ day). Highest intakes were identified in island nations including Maldives, Barbados, the Seychelles, and Iceland, as well as in Malaysia, Thailand, Denmark, South Korea, and Japan. Lowest intakes were in Zimbabwe, Lebanon, the Occupied Palestinian Territory, Botswana, and Guinea-Bissau. In 45 of 187 countries mean intakes were $\geq 250 \mathrm{mg} /$ day, in line with current guidelines. Notably, 100 nations had very low mean consumption $(<100 \mathrm{mg} /$ day), generally in Sub-Saharan African and Asian regions as well as North Africa/Middle East, representing three billion adults and $66.8 \%$ of the world adult population. Mean plant omega 3 consumption was 1371 $\mathrm{mg}$ /day, with a 10-fold range (302 to $3205 \mathrm{mg}$ /day) across regions. By country, intake ranged from $<100$ to $>3000 \mathrm{mg} /$ day. High consumption was seen in Jamaica, China, the UK, Tunisia, Angola, Senegal, Algeria, Canada, and the US. Low intakes were found in Israel, the Solomon Islands, Sri Lanka, Comoros, Saint Lucia, and the Philippines. Although we did not identify sufficient evidence to set a specific optimal intake level for preventing chronic diseases, World Health Organization guidelines suggest mean population plant omega 3 consumption of $\geq 0.5 \%$ of energy intake, or $\geq 1100 \mathrm{mg}$ for a $2000 \mathrm{kcal} /$ day diet. Based on this, 52 of 187 countries met this intake. Among the 135 countries with lower consumption, 61 had intakes $<500 \mathrm{mg} /$ day, substantially below

\footnotetext{
${ }^{1}$ Global Burden of Diseases Nutrition and Chronic Diseases Expert Group (NutriCoDE) (2014)

2 Ibidem

3 Ibidem
} 
current recommendations, representing 800 million adults and $17.8 \%$ of the global adult population ${ }^{1}$

\section{Steady growth in the consumption of animal products}

Globally, there has been increasing pressure on the economy of the livestock sector to respond to the increasing demand for animal protein. The global livestock sector has grown at an unprecedented rate, the driving force of this growth being a combination of global population growth, income growth and urbanization. And the forecasts indicate a further increase in annual meat production from 218 million tons in $1997-$ 1999 to 376 million tons by 2030 .

There is a strong correlation between the level of income and the consumption of animal protein, the consumption of meat, milk and eggs increasing on the expense of discontinued foods. Due to the increase of the accessibility of prices, developing countries realized a higher consumption of meat at much lower levels of GDP compared to the industrialized countries 20-30 years ago.

Table 4. Food of animal origin - consumption per capita

\begin{tabular}{|l|r|r|r|r|r|r|}
\hline \multirow{2}{*}{\multicolumn{1}{|c|}{ Region }} & \multicolumn{3}{|c|}{ Meat (kg per year) } & \multicolumn{3}{c|}{ Milk (kg per year) } \\
\cline { 2 - 7 } & $\begin{array}{c}\mathbf{1 9 6 4 -} \\
\mathbf{1 9 6 6}\end{array}$ & $\begin{array}{c}\mathbf{1 9 9 7 -} \\
\mathbf{1 9 9 9}\end{array}$ & $\mathbf{2 0 3 0}$ & $\begin{array}{c}\mathbf{1 9 6 4 -} \\
\mathbf{1 9 6 6}\end{array}$ & $\begin{array}{c}\mathbf{1 9 9 7 -} \mathbf{1 9 9 9} \\
\mathbf{2 0 3 0}\end{array}$ \\
\hline Global level & 24,2 & 36,4 & 45,3 & 73,9 & 78,1 & 89,5 \\
\hline Developing countries & 10,2 & 25,5 & 36,7 & 28,0 & 44,6 & 65,8 \\
\hline Near East and North Africa & 11,9 & 21,2 & 35,0 & 68,6 & 72,3 & 89,9 \\
\hline Sub-Saharan Africa* & 9,9 & 9,4 & 13,4 & 28,5 & 29,1 & 33,8 \\
\hline Latin America and the Caribbean & 31,7 & 53,8 & 76,6 & 80,1 & 110,2 & 139,8 \\
\hline East Asia & 8,7 & 37,7 & 58,5 & 3,6 & 10,0 & 17,8 \\
\hline South Asia & 3,9 & 5,3 & 11,7 & 37,0 & 67,5 & 106,9 \\
\hline Industrialized countries & 61,5 & 88,2 & 100,1 & 185,5 & 212,2 & 221,0 \\
\hline Countries in transition & 42,5 & 46,2 & 60,7 & 156,6 & 159,1 & 178,7 \\
\hline
\end{tabular}

Nota: * Excludes South Africa

Source: FAOSTAT, 2003.

Urbanization has also strongly influenced the global demand for food stuffs of animal origin. The urbanization stimulated some infrastructure developments, which allowed the creation of cold chains of food transport and conservation, which allowed a modern trade with perishable goods. Compared to the less diversified diets of rural communities, city dwellers have more varied diets, richer in animal protein and fat and characterized by higher consumption of meat, milk and dairy products. Table 4 presents the consumption trends per inhabitant of animal products in different regions and groups of countries. In this regard, there has been a remarkable increase in consumption in countries such as Brazil and China, although levels are still well below

${ }^{1}$ Global Burden of Diseases Nutrition and Chronic Diseases Expert Group (NutriCoDE) (2014) 
the level of consumption in North America and in most industrialized countries. Over time, there has been a general tendency for diets to become richer and more diverse, because of the high-value protein that the livestock sector has offered. Animal products provided high-value proteins, while being important sources of a wide range of essential micronutrients, especially minerals such as iron and zinc, but also vitamins such as vitamin A. However, for a large part of the world's population, especially in the developing countries, the products of animal origin are still deficient foods from the perspective of the balance of the diet. In the same time, the statistical consumption of products of animal origin in some countries and social classes has allowed, however, an excessive intake of fats in the diet of very large categories of population.

The growing demand for animal products also had an adverse impact on the environment. The continuously growing production of the food industry, often located close to urban centers, also involved several risks to the environment and public health. It has been tried to estimate the environmental impact of the food industries. Thus, it has been estimated that the number of people fed per year per hectare varies from 22 for potatoes and 19 for rice to 1 and 2, respectively for beef and lamb (FAOSTAT, 2003).

\section{Consumption of fish evolution}

Despite the changes in demand and supply of fish determined by the dynamics of such resources, the economic climate and environmental conditions, fishing, including aquaculture, has traditionally been and remains an important source of food, jobs and incomes in many countries and communities. Following the massive increase of both inland and marine fish catches in the 1950s and 1960s, world fishery production has declined massively. This reduction followed the general tendency of most of the fishing areas in the world to exploit the maximum available fishing potential. As a result, there was very little opportunity to increase the production of fish caught. In contrast, aquaculture (inland and marine) production, starting from insignificant values, increased at a remarkable rate, offsetting some of the reduction in fish catches in the ocean (Lewis B, Assmann G, eds. 1990; Pimental D. et. al., 1997). Under such conditions, the total supply of fish food and, consequently, the consumption, increased with rates of around $3.6 \%$ per year from 1961, while the population of the world increased by 1.8 $2 \%$ per year. Proteins derived from fish, crustaceans and molluscs accounted for $13.8 \%$ to $16.5 \%$ of the animal protein intake from the diet of the global population. The average consumption/ inhabitant increased from about $9 \mathrm{~kg}$ per year in the beginning of 1960 to $16 \mathrm{~kg}$ in 1997 and exceeding $20 \mathrm{~kg}$ of fish in 2016. The availability of fish and fishery products per capita has doubled in almost 40 years, surpassing the population growth (FAOSTAT, 2003; Ion Monica, 2016).

However, although some progress has been made in regenerating marine fish resources, the overall state of marine resources in the world has not improved radically. The FAO report $(F A O, 2016)$ mentions that almost one third of commercial fish stocks are fished at biologically unsustainable levels, which is a triple percentage point to 1974 . The overall fish production captured in 2014 was 93.4 million tons, including inland water production, which is slightly higher than two years ago. Alaska's black cod was the top 
species, replacing anchovies for the first time in 1998. Record-breaking catches were reported for four extremely valuable groups in 2014 - tuna, lobsters, shrimps, and cephalopods, when there were around 4.6 million fishing vessels worldwide in 2014, of which $90 \%$ in Asia and Africa. Globally, fish provided $6.7 \%$ of all human-consumed protein, providing a rich source of omega-3 fatty acids, vitamins, calcium, zinc and iron.

At global level, about 57 million people were employed in the primary fish production sectors, one third of them in aquaculture. Fishery products accounted for a percentage of the total value of global trade in goods, which is equivalent to more than $9 \%$ of total agricultural exports. Worldwide exports totaled \$ 148 billion in 2014 compared to $\$ 8$ billion in 1976. Developing countries were the source of US $\$ 80$ billion worth of fish exports, delivering net trade revenues higher than those of meat, tobacco, rice, and sugar added.

The role of fish in food models is different from one continent to another, but also at regional and national level. In industrialized countries, where diets generally contain a more diverse range of animal protein, there has been an increase in fish intake per inhabitant from $19.7 \mathrm{~kg}$ to $27.7 \mathrm{~kg}$. This means a growth rate of close to $1 \%$ per year. In this group of countries, the fish contributed with an increasing share to the total protein intake until 1989 (representing between 6.5\% and 8.5\%), but since then its relative importance has gradually decreased, and by 1997, that contribution reached again the values of the mid-80s.

At the beginning of the 1960s, the supply of fish, per inhabitant, in countries with a food deficit, because of the low incomes was, on average, only $30 \%$ of that of to the richest countries. This gap was gradually reduced, so that in 1997 the average consumption of fish in such countries was $70 \%$ of that of the richer economies. Despite the relatively low consumption of food in countries with deficit due to relatively low incomes, the total contribution of animal protein from fish was considerable (almost 20\%). Over the last five decades, however, the share of fish protein in animal protein has decreased slightly, due to the faster increase in consumption of other animal products. Currently, two thirds of the total fish supply come from the catch fishery in inland and marine waters, while the remaining one third is derived from aquaculture. The contribution of inland and marine capture fisheries to food supply per inhabitant has stabilized, around $10 \mathrm{~kg}$ per inhabitant in the period 1984-1998. Any more recent increase in availability per inhabitant was, therefore, obtained from the production of traditional, rural aquaculture, but also from intensive commercial aquaculture of high-value species.

In general, fish contribute up to $180 \mathrm{kcal}$ per capita per day, but reach such high levels only in a few countries where locally grown alternative protein foods are lacking or where there is a strong preference for fish (in Iceland, Japan and some small states). Typically, fish provide about $20-30 \mathrm{kcal}$ per inhabitant per day.

Fish proteins are essential in the diet of densely populated countries, where the total level of protein intake is relatively low. Worldwide, about one billion people rely on fish as their main source of animal protein. Fish dependence is generally higher in coastal areas than in inland areas. About $20 \%$ of the world's population accounts for at least a 
fifth of the animal protein intake on fish production, and some small island states depend almost exclusively on it. The recommendation for increased consumption very common a few decades ago - has become more balanced, because a significant proportion of the world's fish catches are transformed into fish meal and used as feed for industrial animal production and, therefore, it is no longer available for human consumption.

\section{Consumption of fruits and vegetables still lower than recommended}

Fruits and vegetables play an essential role in ensuring a diversified and nutritious diet. Global trends in vegetable production and supply indicate that vegetable production and consumption vary widely across regions (Table 5).

Reduced fruit and vegetable consumption in many regions of the developing world is, however, a persistent phenomenon, even in countries where such food production can be very high (India, China and so on). A nationally representative surveys in India ${ }^{1}$ for example, indicated a constant level of consumption of only 120-140 g per capita per day, with about another $100 \mathrm{~g}$ per capita from roots and tubers and about $40 \mathrm{~g}$ per inhabitant. This is especially true for rural populations in India, who have relatively low incomes. In China, average quantities of fruits and vegetables consumed have increased, especially until 2000 to over 370 g per inhabitant.

Table 5. Provision of vegetables at regional level, 1979 and 2000 (kg per capita per year)

\begin{tabular}{|l|l|l|l|l|l|}
\hline \multicolumn{1}{|c|}{ Region } & \multicolumn{1}{c|}{$\mathbf{1 9 7 9}$} & \multicolumn{1}{|c|}{$\mathbf{2 0 0 0}$} & \multicolumn{1}{|c|}{ Regiunea } & \multicolumn{1}{|c|}{$\mathbf{1 9 7 9}$} & $\mathbf{2 0 0 0}$ \\
\hline Global level & 66,1 & 101,9 & South America & 43,2 & 47,8 \\
\hline Developed countries & 107,4 & 112,8 & Asia & 56,6 & 116,2 \\
\hline Developing countries & 51,1 & 98,8 & Europe & 110,9 & 112,5 \\
\hline Africa & 45,4 & 52,1 & Oceania & 71,8 & 98,7 \\
\hline North and Central America & 88,7 & 98,3 & & & \\
\hline
\end{tabular}

Source: FAOSTAT, 2003.

Generally, only a small minority of the world's population achieves higher average consumption at this point. Until 1998, only 6 of the 14 WHO regions had a fruit and vegetable availability equal to or greater than the recommended intake of $400 \mathrm{~g}$ per inhabitant per day. The relatively favorable situation in 1998 seems to have evolved from a significantly less favorable position in previous years, a fact evidenced by the large increase in the availability of vegetables registered between 1990 and 1998 for most regions. In contrast, fruit availability generally declined between 1990 and 1998 in most regions of the world.

$1 * * *$ India nutrition profile (1998). New Delhi 
The intensification of urbanization at a global level has removed an increasing proportion of the world's population from areas with primary food production, which has had a negative impact on the availability of a varied and nutritious diet, with sufficient fruits and vegetables, but also on the access of the poor from cities on such a diet.

However, when the urbanization has acted in the sense of the general increase in the level of income of the urban population it determined implicitly the raise of the access of the respective population to slightly more diverse dietary diets. On the other hand, investments in peri-urban horticulture on a larger scale also offered some opportunities for increasing food consumption and for maintaining healthier diets.

In 2000, the annual average supply of vegetables per capita was $102 \mathrm{~kg}$, with the highest level in Asia (116 kg), and the lowest levels in South America (48 kg) and Africa (52 kg)

\section{The evolution and forecasting of prices}

After the sharp rise of the prices for almost all the food commodities during 20072012, the world has seen several years of strong supplies, associated with slow growth in demand (Graph 2). This phenomenon has exerted a downward pressure on the international prices of most agricultural commodities, with cereal, beef and sheep meat prices showing short-term rebounds ${ }^{1}$

Graph 2. Evolution of prices for food commodities

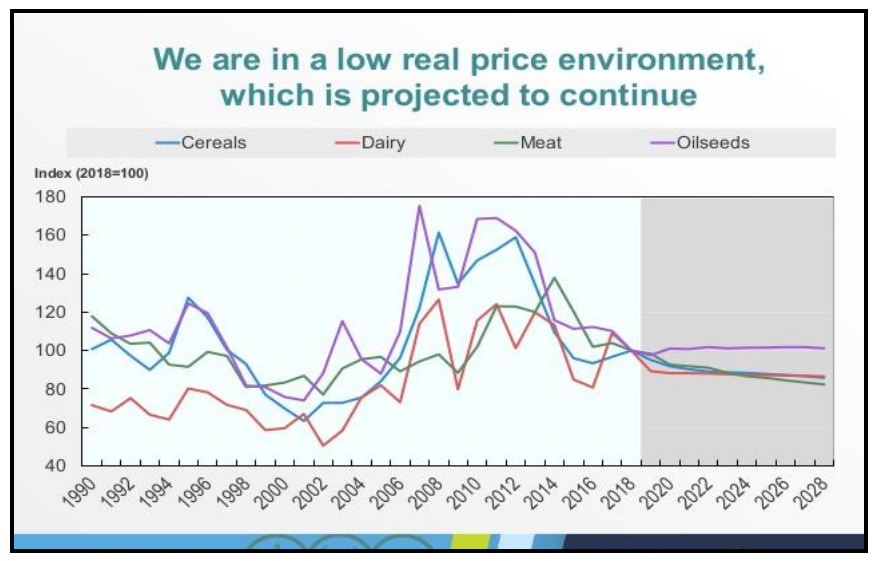

Source: OECD-FAO Agricultural Outlook 2019-2028

For nearly all commodities covered in the OECD-FAO Agricultural Outlook 2019-2028, real prices are projected (2019) to remain at or below current levels over the coming

1 *** OECD-FAO Agricultural Outlook, 2019-2028 
decade, as productivity improvements continue to outpace demand growth. But global food prices rose in October 2019 for the first time in five months, as international quotations for sugar and key cereals increased significantly, according to the Food and Agriculture Organization of the United Nations (FAO).

The FAO Food Price Index averaged 172.7 points in October 2019, some 1.7 percent higher than the previous month and 6.0 percent higher than during October 2018.

World cereal utilization in 2019/20 was forecasted at 2709 million tons, a record high, while world cereal stocks by the end of the 2020 seasons are seen at 849.5 million tons, down 1.5 percent from their opening levels. FAO anticipates the global cereal stock-touse ratio declining modestly to 30.4 percent, still judged a comfortable level. Wheat inventories are expected to rise, while those of maize and rice to decline. ${ }^{1}$

\section{Conclusions}

The main data regarding the consumption of food from medium or high-developed societies mean large-scale changes in dominant or traditional food consumption patterns, which clearly indicate the outline of $a$ "nutrition transition" phenomenon.

This phenomenon refers to some quantitative but also qualitative changes in the eating habits of the majority of the population, in the sense of adopting diets with higher energy density, with a greater role of fats and sugars added in foods, with a higher contribution of saturated fats (especially from animal sources), with reduced intakes of complex carbohydrates and dietary fiber, and reduced intakes of fruits and vegetables. Such dietary changes are accompanied by some modifications of the lifestyles, in the sense of practicing reduced physical activities at work, but also during leisure. This type of nutritional transition did not delay to show some adverse effects on the health of some broad categories of the population, by manifesting nutritional diseases, such as obesity, correlated with an increased incidence of type II diabetes, or with some cardiovascular diseases.

For different reasons, the demand growth for agricultural products has also slowed, especially in some large regions, on the background of the declining growth rates of the population, and also because many countries have reached saturation consumption of food per person, beyond which further rises will be limited.

On the other hand, many poor countries are still facing major food deficits and deficiencies of essential nutrients in the dominant diets of the population. This is because, the mankind still registers a high share of the world's population in poverty which lacks the necessary income for meeting its basic needs. Malnutrition in all its forms remains widespread across the world.

The recent years came with the slowing growth rates of world agricultural production related with the climate changes. In these conditions, all over the world there is high expectation that the agriculture may not be able to grow enough food and commodities of the sort, in order to ensure the needs on long run.

1 *** October rise for global food (2019) 
For the next decade, a still growing global population continue to use increasing amounts of agricultural products as food, feed and for industrial purposes. Much of the additional food demand over the coming decade will originate in regions with high population growth, in particular Sub-Saharan Africa, South Asia, and the Middle East and North Africa.

All these will happen in the conditions of a steady productivity growth in agriculture, anyway expected to stay ahead of food demand, and dominant dietary patterns will continue to evolve due to rising incomes and ongoing urbanization.

In future, agriculture will remain a significant contributor to global greenhouse gas emissions, mostly from livestock, as well as rice and synthetic fertilizers, which are expected to grow even if on a declining carbon intensity as productivity increases.

The international trade will remain essential for food security in a growing number of food-importing regions. It also will remain an important source of incomes and livelihoods in exporting regions such as Latin America and the Caribbean region. The Black Sea region will consolidate its position as a leading exporter of wheat and coarse grains, with most exports going to the Middle East and North Africa.

World agricultural markets will face different new uncertainties that add to the traditionally high risks facing agriculture. On the supply side, these include the spread of diseases such as African Swine Fever, growing resistance to antimicrobial substances, regulatory responses to new plant breeding techniques and responses to increasingly likely extreme climatic events. On the demand side, they include evolving diets, reflecting perceptions with respect to health and sustainability issues, and policy responses to alarming trends in obesity. The coronavirus pandemic will also produce a high impact both on the side of supply/demand and on the price evolution for the most food (and not only) production. Uncertainty will influence all the trading agreements between the most important players on world agricultural markets. New opportunities of demand and the escalation of ongoing trade tensions have the potential to reduce and redirect trade, ${ }^{1}$ with strong consequences for the international availability of food products on the domestic markets

\section{References}

Drewnowski A., Popkin B.M. (1997). The nutrition transition: new trends in the global diet. Nutrition Reviews, p. 31-43.

Ion M. (2016) Pentru prima data în istorie, consumul global de pește pe cap de locuitor se ridică mai sus de 20 de kilograme anual, Radio România, 08/07/2016, available at http://www.rador.ro/ 2016/07/08/pentru-prima-data-in-istorie-consumul-global-de-peste-pe-cap-de-locuitorse-ridica-mai-sus-de-20-de-kilograme-anual/

Guo X et a.l. (2000) Structural change in the impact of income on food consumption in China 1989-1993. Economic Development and Cultural Change, p.737-760

Ritchie H., Roser M. (2020) Diet Compositions. available at https://ourworldindata.org/dietcompositions

1 OECD-FAO Agricultural Outlook 2019-2028 
Lewis B, Assmann G, eds. (1990) The social and economic contexts of coronary prevention. London, Current Medical Literature

Pimental D et al. (1997). Water resources: agriculture, the environment and society. Bioscience, 47:97-106.

OECD-FAO Agricultural Outlook 2019-2028

Food and Agriculture Organization of the United Nations (2002) World agriculture: towards 2015/2030. Summary report. Rome

FAO (2003) Global and regional food consumption patterns and trends, available at http://www.fao.org/3/ac911e/ac911e05.htm

FAO (2016). The state of world fisheries and aquaculture contributing to food security and nutrition for all, available http://www.fao.org/3/a-i5555e.pdf

Global Burden of Diseases Nutrition and Chronic Diseases Expert Group (NutriCoDE) (2014) Global, regional, and national consumption levels of dietary fats and oils in 1990 and 2010: a systematic analysis including 266 country-specific nutrition surveys, available at https://www. bmj.com/content/348/bmj. g2272

Ministry of Human Resource Development, Government of India, Department of Women and Child Development (1998). India nutrition profile

World Health Organization, Nutrition (2003). Available at https://www.who.int/nutrition/ topics/3_foodconsumption/en/index6.html

*** October rise for global food (2019), available at priceshttp://www.fao.org/ news/story/en/item/1246478/icode/

*** Food Molecules (2020), available at https://www.worldofmolecules.com/foods/ 